\title{
The Influences of Sodium Hexametaphosphate (SHMP) and Methyl Orange (MO) on Enzyme Hydrolysis of Excess Sludge
}

\author{
Cao Lu, Xue Fei, Liu Eryan, Li Dengxing*, Asif Hussain, Taimore Hussain \\ College of Environmental Science and Engineering, Donghua University, Shanghai, China \\ Email address: \\ 1561611584@qq.com(Cao Lu),xuefeiwin@outlook.com (Xue Fei), 1130193109@qq.com (Liu Eryan), \\ lidengxin@dhu.edu.cn (Li Dengxing), asif.fuuast@hotmail.com (A. Hussain), taimoor852@yahoo.com (T. Hussain) \\ ${ }^{*}$ Corresponding author
}

To cite this article:

Cao Lu, Xue Fei, Liu Eryan, Li Dengxing, Asif Hussain, Taimore Hussain. The Influences of Sodium Hexametaphosphate (SHMP) and Methyl Orange (MO) on Enzyme Hydrolysis of Excess Sludge. International Journal of Environmental Protection and Policy.

Vol. 6, No. 2, 2018, pp. 42-49. doi: 10.11648/j.ijepp.20180602.14

Received: April 1, 2018; Accepted: May 12, 2018; Published: June 21, 2018

\begin{abstract}
The effect of Sodium Hexametaphosphate (SHMP) and Methyl Orange (MO) on the hydrolysis of sludge were investigated under the optimum condition of alkaline protease hydrolysis. The results showed that as the concentration of SHMP was increased, the content of Soluble Chemical Oxygen Demand (SCOD), protein, and polysaccharide in the sludge hydrolysate gradually raised. When the concentration of SHMP was $0.1 \mathrm{~g} / \mathrm{g} \cdot \mathrm{tss}$, the contents of SCOD, protein, and polysaccharide increased by $17.16 \%, 50 \%$, and $9.72 \%$ respectively. With the increase of MO concentration, SCOD decreased gradually. When the concentration of SHMP was $0.02 \mathrm{~g} / \mathrm{g} \cdot \mathrm{tss}$, the SCOD decreased by $10.3 \%$. An increase of $13 \%$ in the protein content was noted, when the concentration was $0.02 \mathrm{~g} / \mathrm{g}$.tss. On the contrary, there was a slight reduction of the polysaccharide content i.e. $2.4 \%$. The concentration of the polysaccharide was found to be the lowest at the concentration of $0.002 \mathrm{~g} / \mathrm{g} \cdot \mathrm{tss}$. From the aforementioned results combined with three-dimensional fluorescence map of sludge EPS, it was found that SHMP promoted the hydrolysis of sludge by alkaline protease and accelerated the dissolution of intracellular organic matter. Herein, the MO inhibited alkaline protease hydrolysis of sludge, which hindered the dissolution of intracellular organics.
\end{abstract}

Keywords: Alkaline Protease, Sodium Hexametaphosphate, Methyl Orange, Three-Dimensional Fluorescence Spectroscopy

\section{Introduction}

With the rapid development of Chinese industry, the effluent of industrial wastewater and industrial sludge is an emerging problem. The discharge of printing and dyeing wastewater accounts for $10 \%$ of the country's industrial wastewater. The annual average discharge of textile printing and dyeing wastewater is about 2.1 billion tons and the annual average sludge discharge is about 21 million tons [1]. Printing and dyeing sludge, mainly including biochemical sludge and materialized sludge, comes from the various processes of printing and dyeing wastewater treatment channels. Biochemical sludge remained after biological treatment of printing and dyeing wastewater that mainly comes from the activated sludge processing unit. Its organic content is high (generally less than 50\%) $[2,3]$ and sludge particles are small floccules with high moisture content, relatively low density and poor stability. Materialized sludge is obtained by chemical treatment (such as coagulation, oxidation, and electrolysis) [4]. It mainly comes from the coagulation and sedimentation of wastewater or coagulation flotation unit. Its sludge particles are large and easy to settle. The moisture content is low while relative density is high and stability is good [5].

The chemical composition of printing and dyeing sludge is complex. It contains a large number of toxic organic pollutants (such as dyes, additives, polycyclic aromatic hydrocarbons $\mathrm{PAH}$, aromatic amines) and heavy metal elements (such as zinc, copper, lead and chromium) [7]. Dyeing sludge is a kind of strong pollutants and was identified as hazardous industrial waste [6]. The nature of printing and dyeing sludge is directly 
influenced by the production methods, types, contents of dyes, additives. The composition and properties of printing and dyeing sludge in different factories are different, which increases the difficulty of the treatment of printing and dyeing sludge.

The disposal methods of dyeing sludge in the worldwide are mostly based on the treatment and disposal methods of urban sludge, mainly including landfill, incineration and land use. In recent years, scholars have studied some new sludge treatment technologies. Zhang Hedong et al. used microwave pyrolysis technology to treat dyeing sludge. It was found that adding $\mathrm{CaO}$ at $550^{\circ} \mathrm{C}$ can maximize the surface area of peat. It enriched with large number of heavy metal elements in the dyeing mud on the peat surface [8]; Feng Yinfang used ultrasonic-coupled potassium ferrate to enhance the dewatering of the dyeing sludge and found that low acoustic energy density and short ultrasonic time can promote sludge dewatering performance. The addition of $60 \mathrm{mg} / \mathrm{g}$ potassium ferrate also contributes to its dehydration [9]; Chen Hao's research shows that the use of acidophilus acid bioleaching combined with Fenton oxidation method can increase the organic carbon content in the sludge supernatant from $20.8 \mathrm{mg} / \mathrm{L}$ to $356.6 \mathrm{mg} / \mathrm{L}$ and the water content from $88.75 \%$ to $82.82 \%$ [10].

Luo Kun studied extra-enzymes to strengthen the hydrolysis of excess sludge and found that added enzymes could promote the dissolution of suspended solids in sludge and the degradation of macromolecule. The addition of enzymatic hydrolysis technology can destroy the EPS structure of the sludge and allow the dissolution of intracellular organic substances, thereby reducing the solid sludge and achieving the purpose of reduction. This method has the advantage of short digestion time, good digestion performance [11], and economical efficiency [12], with no environmental side-effect [13]. However, little research has been done to apply this technique to the treatment of printing and dyeing sludge. In this paper, the dyestuff methyl orange and sodium hexametaphosphate (a printing and dyeing assistant) were selected as the research object to simulate the dyeing sludge and to study its effect on the enzymatic hydrolysis of sludge.

\section{Material and Methods}

\subsection{Reagents and Instruments}

The sludge was taken from the Songjiang Sewage Treatment Plant in Shanghai. It is a resultant sludge from the secondary sedimentation tank. Samples were stored at $4{ }^{\circ} \mathrm{C}$ and refrigerated. Sludge properties are shown in Table 1.

Table 1. Sludge properties.

\begin{tabular}{ll}
\hline Sludge properties & Value \\
\hline $\mathrm{pH}$ & 6.88 \\
$\mathrm{SCOD}\left(\mathrm{mg} \cdot \mathrm{L}^{-1}\right)$ & 104 \\
$\mathrm{TSS}\left(\mathrm{g} \cdot \mathrm{L}^{-1}\right)$ & 4.131 \\
$\mathrm{VSS}\left(\mathrm{g} \cdot \mathrm{L}^{-1}\right)$ & 2.77 \\
Polysaccharide $\left(\mathrm{mg} \cdot \mathrm{g}^{-1}\right)$ & 3.68 \\
protein $\left(\mathrm{mg} \cdot \mathrm{g}^{-1}\right)$ & 0.48 \\
SOUR $\left(\mathrm{mgO}_{2} / \mathrm{gMLSS} \cdot \mathrm{h}\right)$ & 11.3 \\
\hline
\end{tabular}

SOUR is the rate of deoxygenation, characterizing sludge activity. (SOUR between 5 and10 means sludge activity is poor, and 10-40 activity is better [14-16])

Alkaline protease was selected for the experiment. The basic parameters of the enzyme are shown in Table 2.

Table 2. Enzyme parameters.

\begin{tabular}{ll}
\hline Alkaline protease & Value \\
\hline Enzyme Activity $(\mathrm{U} / \mathrm{mg})$ & $\geq 2000$ \\
Suitable $\mathrm{pH}$ & $7-12$ \\
Suitable temperature $\left({ }^{\circ} \mathrm{C}\right)$ & $40-60$ \\
\hline
\end{tabular}

Reagents: Methyl Orange (MO), Sodium Hexametaphosphate (SHMP), Phosphate Buffer Solution $\mathrm{pH}=8.0$, Potassium Dichromate Standard Solution (Analytical Pure), Tricholine Titril (Analytical Pure), Concentrated Sulfuric Acid (Analytical Pure), Sulfuric Acid Silver (Analytical Pure), Mercury Sulfate (Analytic Pure), etc.

Main instruments: Analytical balance (JA31002, Shanghai), water bath thermostatic oscillator (DKY-11, Shanghai), centrifuge (SL-16R, Theermo Fisher, USA), microwave oven (M1-211A21L, Midea), thermostatic drying oven (BPH -6063, Shanghai), Fluorescence Spectrometer (QuantMaster 40, USA), UV Spectrophotometer (TV-1810, Shanghai), Dissolved Oxygen Meter.

\subsection{Analytical Methods}

Analytical methods: TSS and VSS were determined by gravimetric method; CODcr was determined by microwave digestion-the potassium dichromate method [17, 18]. The chemical oxygen demand of the supernatant was measured after SCOD was centrifuged at $11000 \mathrm{r} \cdot \mathrm{min}-1$ for 20 minutes. Polysaccharides were determined using the sulfuric acid-anthrone method [19]; Proteins were determined using the Coomassie brilliant blue method [20]. SOUR test method is sensitive electrode-dissolved oxygen analyzer method $[14,16]$.

\subsection{Experimental Procedure}

Take $12250 \mathrm{ml}$ conical flasks, numbered 1-12. Add $50 \mathrm{ml}$ of sludge to the $1-12$ conical flask and add $0.1 \mathrm{~g} / \mathrm{g} \cdot$ tss of alkaline protease. The 12 Erlenmeyer flasks were divided into two groups, from group 1-6 were group A, and $0 \mathrm{~g} / \mathrm{g} \cdot \mathrm{tss}$, $0.01 \mathrm{~g} / \mathrm{g} \cdot \mathrm{tss}, \quad 0.03 \mathrm{~g} / \mathrm{g} \cdot \mathrm{tss}, \quad 0.05 \mathrm{~g} / \mathrm{g} \cdot \mathrm{tss}, \quad 0.1 \mathrm{~g} / \mathrm{g} \cdot \mathrm{tss}, \quad$ and $0.15 \mathrm{~g} / \mathrm{g} \cdot$ tss were respectively added SHMP, Nos. $7-12$ are in Group B, and $0 \mathrm{~g} / \mathrm{g} \cdot \mathrm{tss}, 0.002 \mathrm{~g} / \mathrm{g} \cdot \mathrm{tss}, 0.005 \mathrm{~g} / \mathrm{g} \cdot \mathrm{tss}, 0.01 \mathrm{~g} / \mathrm{g} \cdot \mathrm{tss}$, $0.015 \mathrm{~g} / \mathrm{g} \cdot \mathrm{tss}$, and $0.02 \mathrm{~g} / \mathrm{g} \cdot \mathrm{tss}$ MO were added respectively. 
Adjust the $\mathrm{pH}$ to 11 . Place the 12 Erlenmeyer flasks in a thermostatic oscillator, reacted at $130 \mathrm{r} / \mathrm{min}$ and $55^{\circ} \mathrm{C}$ for $4 \mathrm{~h}$ and then take them out. Put them into $100 \mathrm{ml}$ centrifuge tubes and centrifuged at $11000 \mathrm{r} / \mathrm{min}$ for 20 minutes. The sample was filtered.

Take 6 Erlenmeyer flasks, numbered 1-6, add 50ml sludge to the 1-6 Erlenmeyer flask respectively, No. 1 is blank control group, No. 2 sample is added with $0.1 \mathrm{~g} / \mathrm{g} \cdot \mathrm{tss}$ alkaline protease. No. 3 and No. 4 were sequentially added with $0.1 \mathrm{~g} / \mathrm{g} \cdot \mathrm{tss}$ SHMP and $0.02 \mathrm{~g} / \mathrm{g} \cdot$ tss MO. Sample Nos. 5 and 6 were dosed with $0.1 \mathrm{~g} / \mathrm{g} \cdot$ tss SHMP and $0.02 \mathrm{~g} / \mathrm{g} \cdot \mathrm{tss} \mathrm{MO}$, respectively. Adjust the $\mathrm{pH}$ to 11 . Place the 6 Erlenmeyer flasks in a thermostatic oscillator, reacted at $130 \mathrm{r} / \mathrm{min}$ and $55^{\circ} \mathrm{C}$ for $4 \mathrm{~h}$ and then take them out. Put them into $100 \mathrm{ml}$ centrifuge tubes and centrifuged at $11000 \mathrm{r} / \mathrm{min}$ for 20 minutes. The samples were filtered.

Three-dimensional fluorescence spectrometry conditions: excitation wavelength $\lambda$ ex is $220 \mathrm{~nm}$ to $550 \mathrm{~nm}$, emission wavelength $\lambda$ em is $240 \mathrm{~nm}$ to $700 \mathrm{~nm}$, wavelength interval is $5 \mathrm{~nm}$, and slit width is $0.8 \mathrm{~nm}$.

\section{Results and Discussion}

\subsection{Effect of SHMP on Enzymatic Hydrolysis of Sludge}

The effect of SHMP on the hydrolysis of organic matter, proteins, and polysaccharides from alkaline protease hydrolysis sludge is shown in Figure 1 and Figure 2.

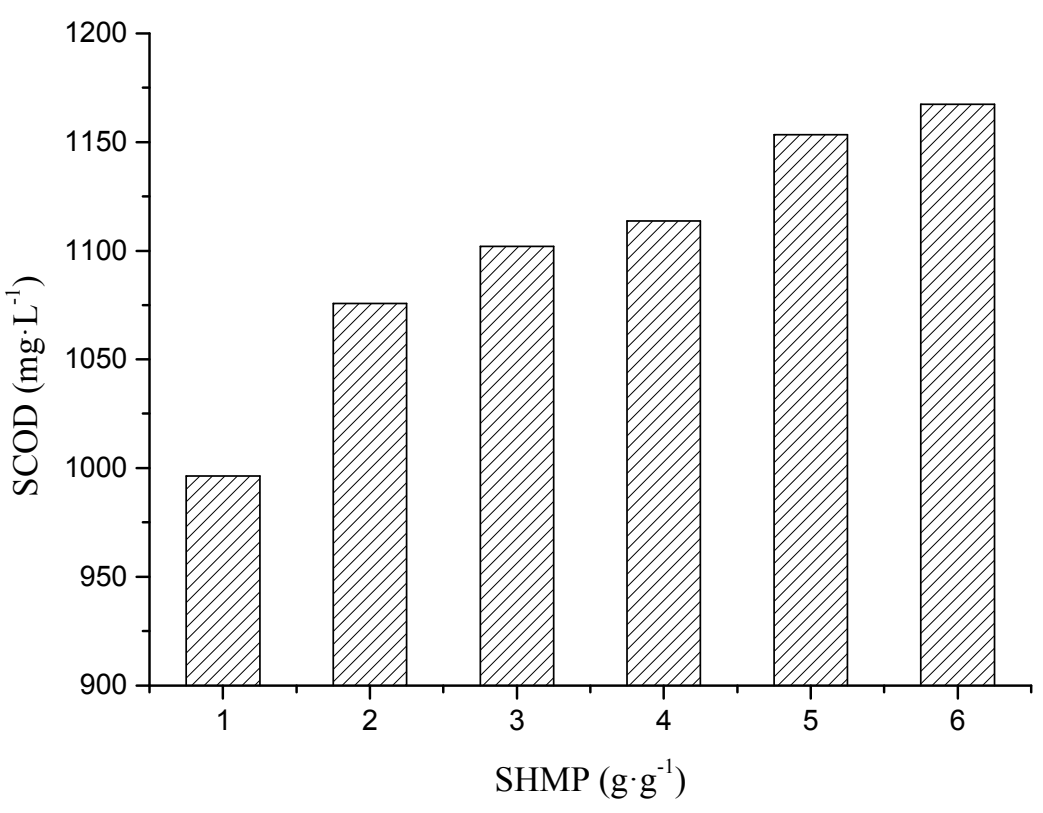

Figure 1. SCOD changes with SHMP concentration.

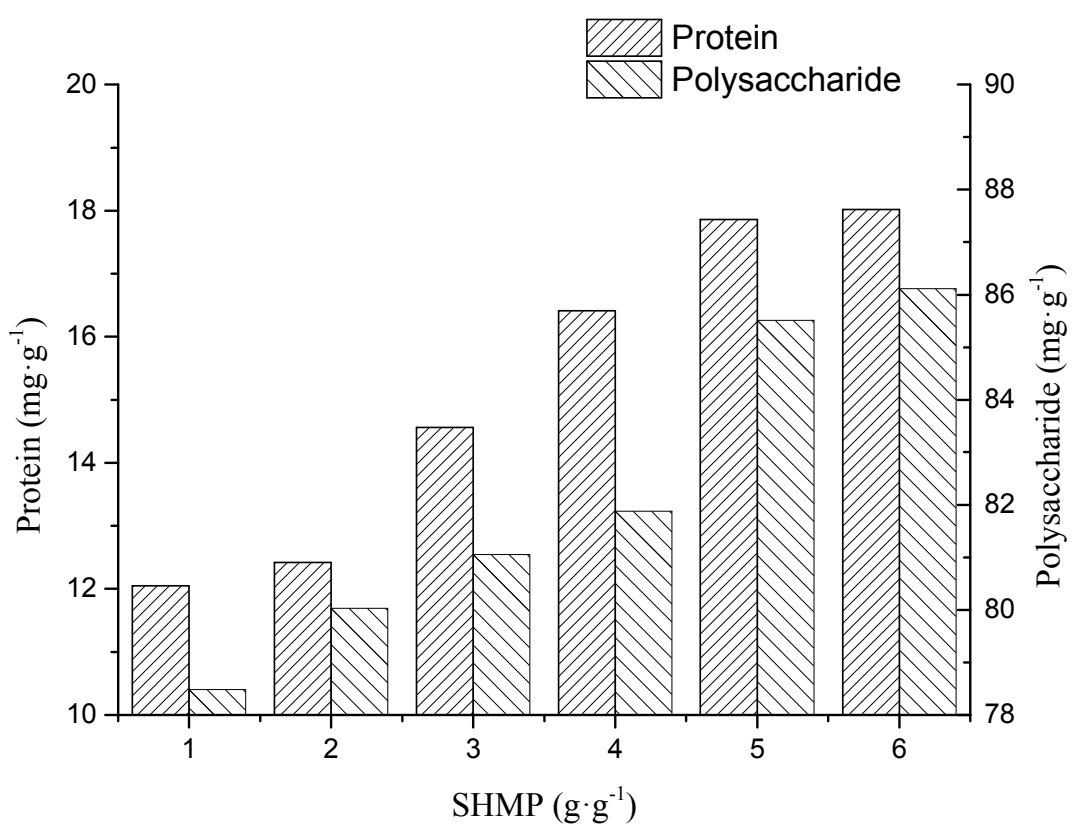

1-6 are SHMP concentrations of $0,0.01,0.03,0.05,0.1,0.15 \mathrm{~g} / \mathrm{g} \cdot \mathrm{tss}$, respectively.

Figure 2. Protein and polysaccharide content changes with SHMP concentration. 
As can be seen in Figure 1, SCOD gradually increases with the increase of SHMP concentration. When the SHMP was added at $0.01 \mathrm{~g} / \mathrm{g} \cdot \mathrm{tss}$, the SCOD value was $1075 \mathrm{mg} / \mathrm{L}$. Compared to the case where SHMP was not added (SCOD was $996.44 \mathrm{mg} / \mathrm{L})$, SCOD increased by $7.9 \%$ When the dosage reached $0.1 \mathrm{~g} / \mathrm{g} \cdot \mathrm{tss}$, the SCOD value reached 1153.38 $\mathrm{mg} / \mathrm{L}$, an increase of $17.16 \%$.

From Figure 2, it can be seen that with the increase of SHMP concentration, the content of protein and polysaccharide gradually increases. The protein content was $12 \mathrm{mg} / \mathrm{g}$ when no contaminants were added. When the dosage was $0.01 \mathrm{~g} / \mathrm{g} \cdot \mathrm{tss}$, the protein concentration reached $18 \mathrm{mg} / \mathrm{g}$, an increase of $50 \%$. The polysaccharide content increased from $78.48 \mathrm{mg} / \mathrm{g}$ to $86.11 \mathrm{mg} / \mathrm{g}$, which was an increase of $9.72 \%$.

The content of SCOD, protein and polysaccharide in the hydrolysate increased after the addition of SHMP. The reason may be that sodium hexametaphosphate acts as a dispersant, which can more evenly disperse the sludge and enzyme particles, thereby increasing the contact between the enzyme and the sludge. At the same time as a surfactant, it can promote the dissolution of carbohydrates and proteins [21]. The EPS structure was broken which increased the contact between the enzyme and the substrate and promoted the hydrolysis of the enzyme.

\subsection{Effect of MO on Enzymatic Hydrolysis of Sludge}

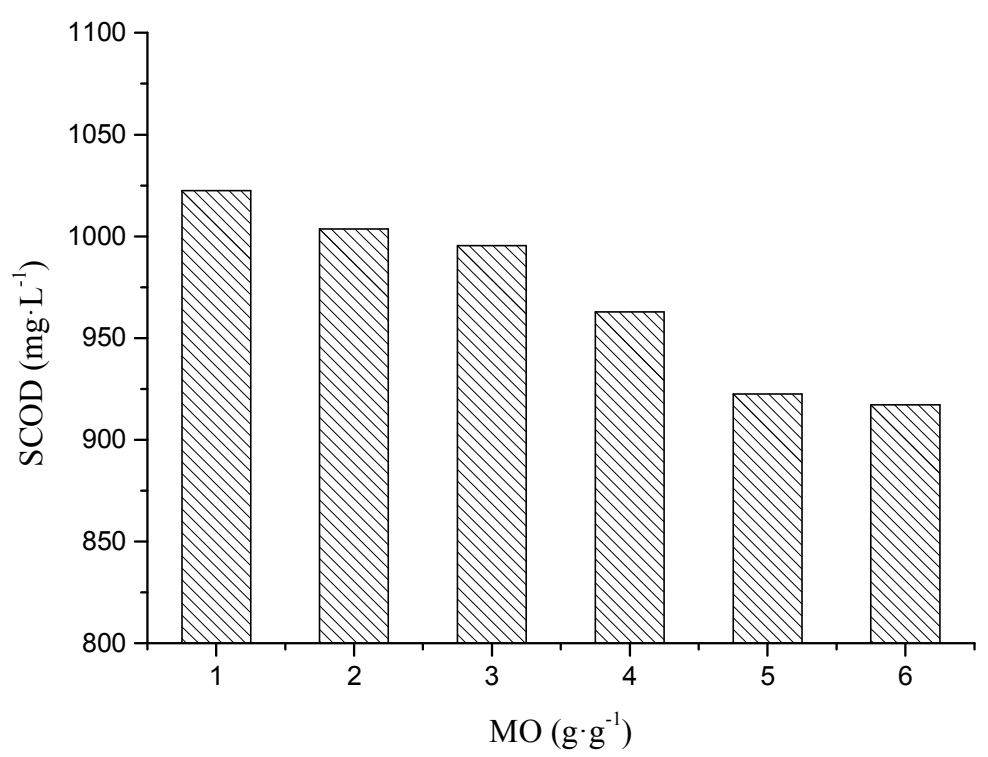

Figure 3. SCOD changes with $M O$ concentration.

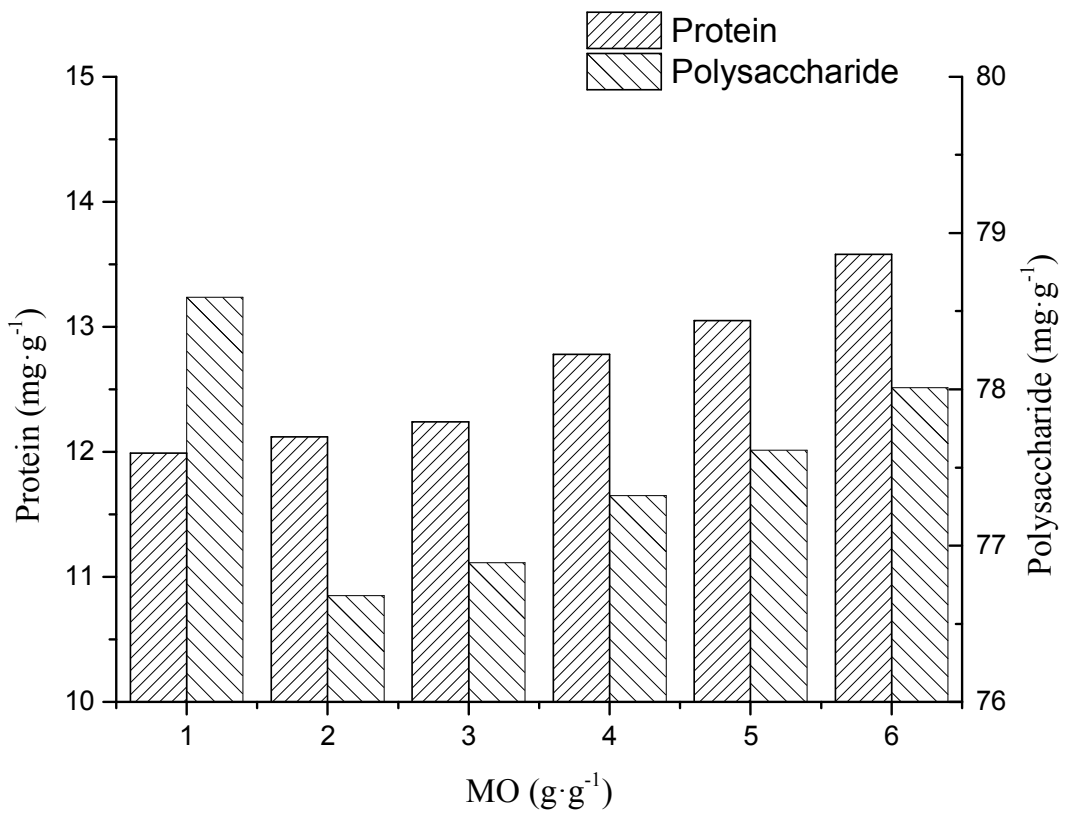

1-6 are MO concentrations of $0,0.01,0.03,0.05,0.1,0.15 \mathrm{~g} / \mathrm{g} \cdot \mathrm{tss}$, respectively.

Figure 4. Protein and polysaccharide content changes with MO concentration. 
From Figure 3, it can be seen that as the MO content increases, the SCOD value gradually decreases. When the MO dosage was $0.02 \mathrm{~g} / \mathrm{g} \cdot \mathrm{tss}$, the SCOD value was $917.27 \mathrm{mg} / \mathrm{L}$. Compared with the non-dosed MO (SCOD value 1022.4 $\mathrm{mg} / \mathrm{L})$, the SCOD was reduced by $10.3 \%$.

As can be seen from Figure 4, the protein content increased with increasing MO concentration. When $0.02 \mathrm{~g} / \mathrm{g} \cdot \mathrm{tss} \mathrm{MO}$ was added, the protein content reached $13.58 \mathrm{mg} / \mathrm{g}$, an increase of $13 \%$. With the increase of MO concentration, the polysaccharide content decreased firstly. After the concentration of MO was more than $0.002 \mathrm{~g} / \mathrm{g} \cdot \mathrm{tss}$, the polysaccharide content gradually increased but it was always lower than that when it was not added. When $0.002 \mathrm{~g} / \mathrm{g}$.tss $\mathrm{MO}$ was added the polysaccharide concentration was reduced from $78.59 \mathrm{mg} / \mathrm{g}$ when undosed to $76.68 \mathrm{mg} / \mathrm{g}$, a decrease of $2.4 \%$. When the MO dosage was $0.02 \mathrm{~g} / \mathrm{g} \cdot \mathrm{tss}$, the polysaccharide content was $78.01 \mathrm{mg} / \mathrm{g}$ and the polysaccharide was reduced by $0.7 \%$.

After the addition of MO, SCOD gradually decreased that indicating the dissolution of organic matter in the sludge was reduced. The reason may be that the added MO will adsorb on the surface of the sludge which hindering the contact of the enzyme with the sludge and at the same time hindering the dissolution of the organic matter [22]. The gradual increase in protein content may be due to the addition of MO to stimulate organisms such as microorganisms and bacteria in the sludge. As the concentration of MO increases the microorganisms in the sludge will secrete more EPS to resist extracellular toxic substances through metabolism in the new city by adsorption in the environment or autolysis of the cells, thereby protecting themselves [23]. The polysaccharide content decreased first, probably due to the adsorption of MO on the sludge surface. It reduces the content of dissolved polysaccharides. At the same time, the amount of polysaccharides secreted by microorganisms is less and with the increase of the concentration of MO the polysaccharides secreted by microorganisms gradually increases.

\subsection{Three-Dimensional Fluorescence Changes of EPS After Sludge Hydrolysis}

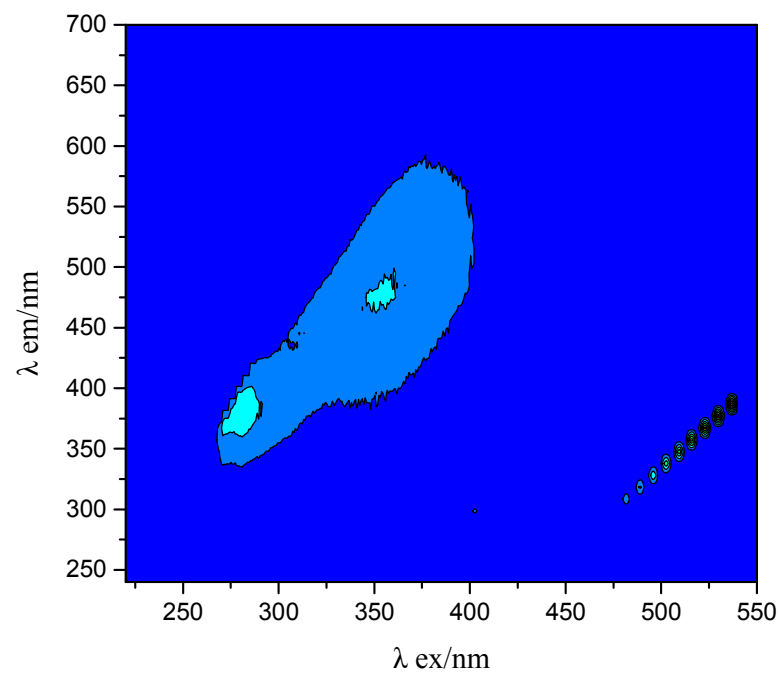

(a)

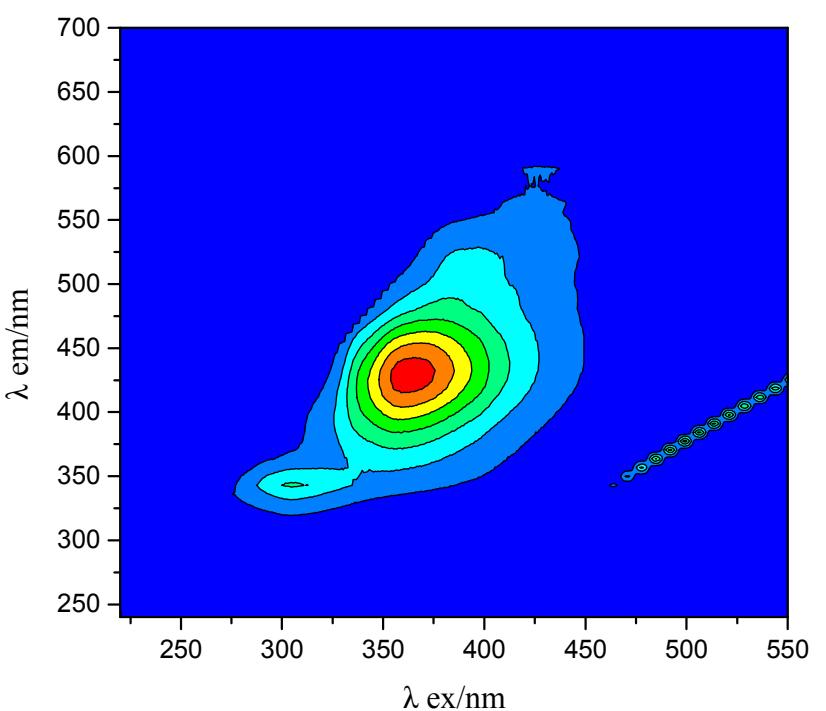

(b)

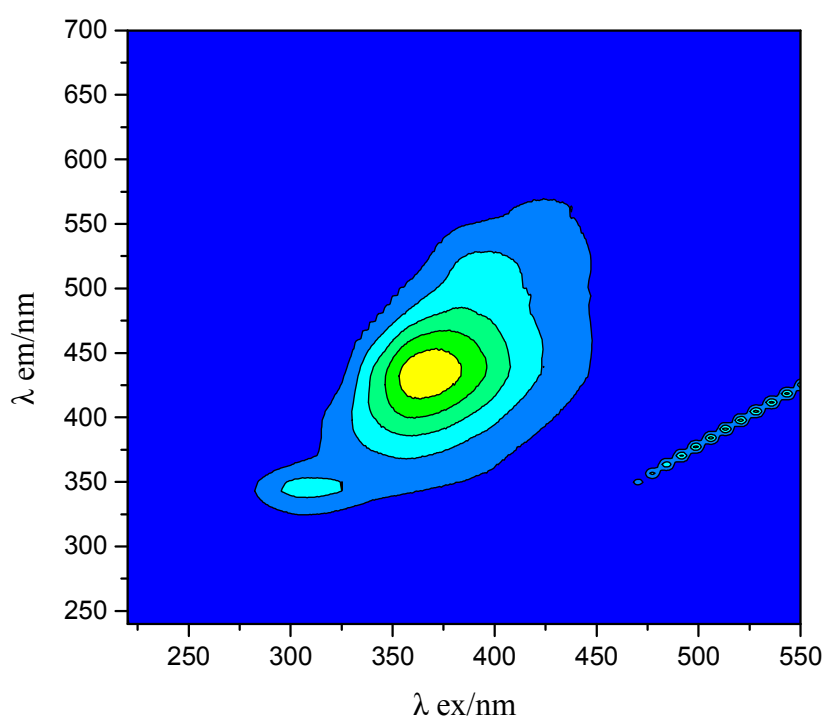

(c)

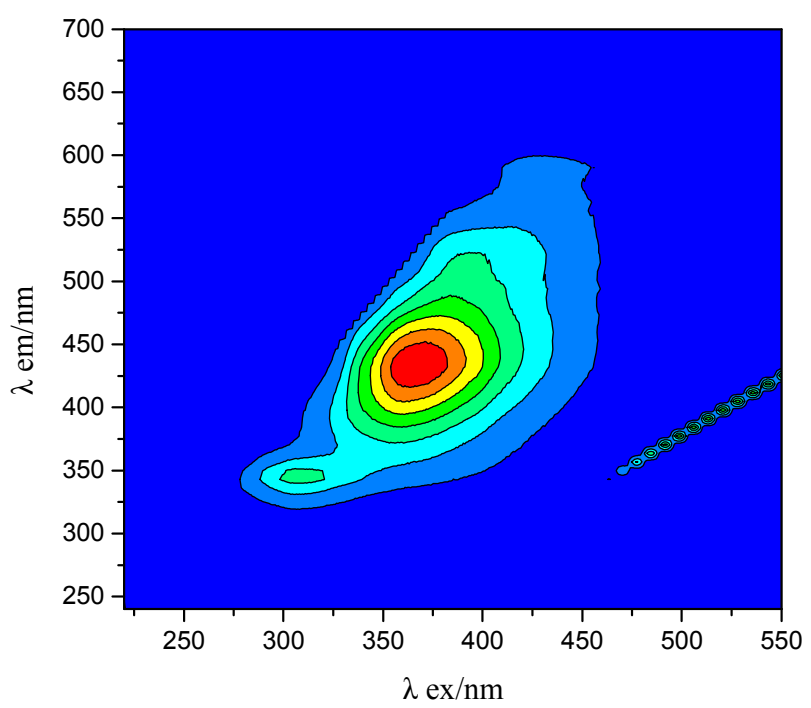

(d) 


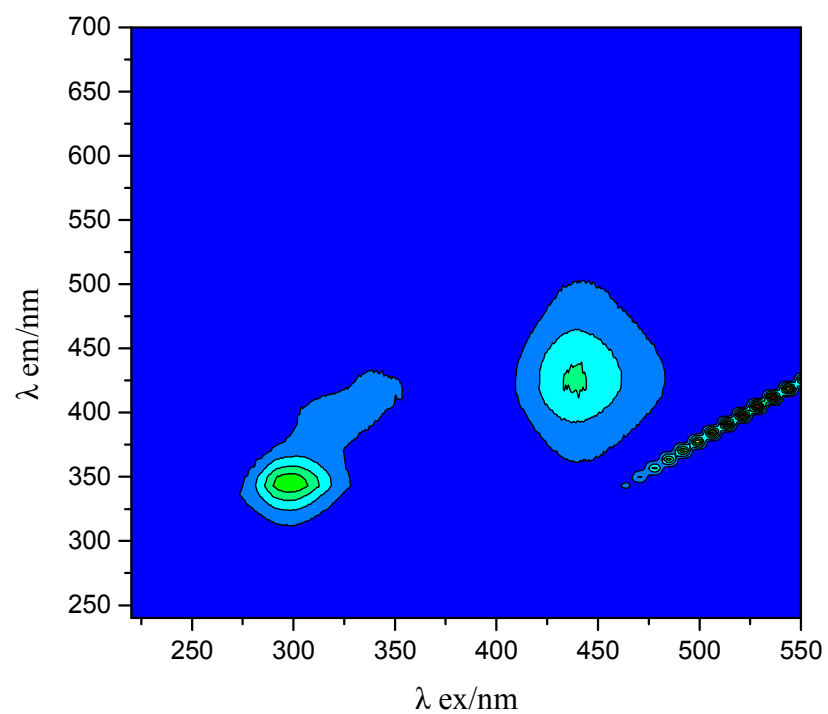

(e)

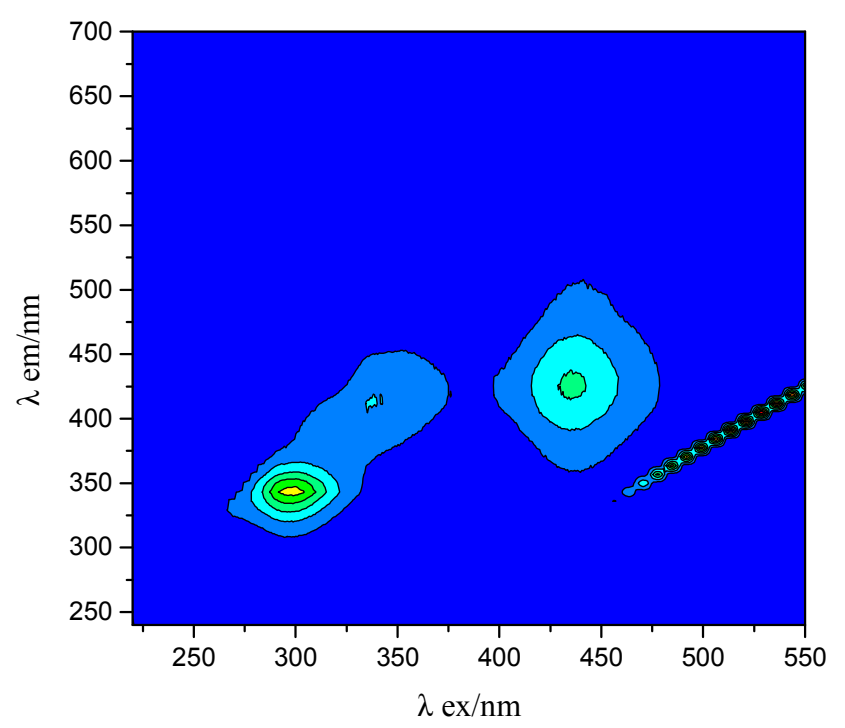

(f)

Figure 5. EPS three-dimensional fluorescence image of sludge hydrolysis.

(a) raw sludge, (b) sludge $+0.1 \mathrm{~g} / \mathrm{g} \cdot \mathrm{tss}$ alkaline protease, (c) sludge + $0.1 \mathrm{~g} / \mathrm{g} \cdot$ tss SHMP, (d) sludge $+0.1 \mathrm{~g} / \mathrm{g} \cdot$ tss alkaline protease $+0.1 \mathrm{~g} / \mathrm{g} \cdot$ tss SHMP, (e) sludge $+0.1 \mathrm{~g} / \mathrm{g}$.tss Alkaline protease $+0.02 \mathrm{~g} / \mathrm{g} \cdot$ tss $\mathrm{MO}$, (f) sludge + $0.02 \mathrm{~g} / \mathrm{g} \cdot$ tss $\mathrm{MO}$

The fluorescence intensity of $\mathrm{c}$ is greater than a, indicating that the addition of SHMP reacts for a large amount of organic matter after being reacted for $4 \mathrm{~h}$ at $55^{\circ} \mathrm{C}$ and $\mathrm{pH}=11$. The fluorescence intensity of $d$ is greater than $b$, which indicates that under the same reaction conditions, the content of protein and humus dissolved in $0.1 \mathrm{~g} / \mathrm{g} \cdot$ tss was increased compared with the case where it was not added, which is consistent with the results of 3.1 studies. It is better illustrated that SHMP promotes the hydrolysis of sludge by alkaline protease.

In general, the fluorescence intensity of $f$ was less than $b$, and the fluorescence intensity of humus was greatly reduced after MO was added, but the protein fluorescence intensity of $f$ was higher than that of $b$. It shows that the total amount of organics dissolved after the addition of MO was reduced, but the protein content was increased. This is because MO is adsorbed on the surface of sludge particles, which hinders the contact of the enzyme with the sludge substrate and limits the dissolution of intracellular organic substances. The toxicity of MO stimulated the living organisms in the sludge to secrete EPS, which is consistent with the results of the study of 3.2 , indicating that MO has an inhibitory effect on alkaline protease hydrolysis of sludge.

\section{Conclusions}

SHMP that acts as a surfactant, enables more uniform dispersion of sludge and enzymes, and accelerates the dissolution of proteins and carbohydrates, thereby destroying the EPS structure and increasing the contact between the enzyme and the substrate. The addition of SHMP can increase the content of SCOD value, protein and polysaccharide, and it can be considered that it promotes the hydrolysis of sludge by alkaline protease.

MO can be adsorbed on the surface of sludge particles, which hinders the dissolution of organic matter. However, due to its toxicity, the microorganisms in the sludge stimulate the secretion of proteins and then form a protective layer on the surface. The content of SCOD and polysaccharide decreases when MO was added, but the protein content increases. According to the three-dimensional fluorescence map, it can be confirmed that it inhibites alkaline protease hydrolysis of sludge.

\section{Acknowledgements}

First of all, I would like to thank my graduate tutor, Professor Li Dengxin, professor of environmental science and engineering at Donghua University. His research direction is the treatment and disposal of solid waste. Professor Li is a very good teacher. $\mathrm{He}$ is serious and responsible in teaching, treats scientific research rigorously, respects facts, and seeks truth from facts. When I was a junior, I had the privilege of reading Professor Li's article and inspired my interest in solid waste disposal. It is also very fortunate to be a student of Professor Li. In my research, Professor Li gave me a lot of help. When selecting topics, he asked me to choose topics that I was interested in, tap into my research potential, help me identify research topics, and maximize my research enthusiasm. After identifying the topic, I read a lot of references. Sometimes Mr. Li will send me some articles that he thinks are valuable and relevant to my topic. This also helped me understand the latest trends in my major. In the course of scientific research, he continuously inspired me and cultivated my attitude of diligence and work. Whenever I have a problem, he can solve the problem for me and help me through the difficulties.

Secondly, I would like to thank Xue Fei, a senior member of the sludge research team of our research group. He is a Ph.D. in Environmental Science and Engineering. His 
research topic is about the treatment and disposal of sludge. Under his guidance, I slowly learned about my topic. I follow his steps and carry out scientific research step by step and conduct in-depth research. He helped me very much in the process of understanding the subject, carrying out the project and conducting in-depth research. He gave me a lot of tips for reading the literature and doing experimental techniques. These techniques saved me a lot of time during the experiment. His teachings have benefited me a lot. Xue Fei, like my second tutor, taught me my experience and led me to do research. The completion of this paper is inseparable from the help of Xue Shixiong. I was able to innovate on the basis of his research.

At the same time, I would also like to thank my sister-in-law, Liu Eryan, who is a first-year student in the Master of Science in Environmental Science and Engineering. During my experimentation, she always helped me with some trivial matters and helped me to complete my experiment together. With her help, my experimental efficiency has greatly improved. Finally, thanks to two foreign friends, Asif and Taimore, both of whom are also major in environmental science and engineering. Their English is very good. When I wrote the English paper, they gave me some suggestions, how to write an English abstract, and so on. After I finished the English paper, they also read it carefully and gave me some comments on the wording. This helped my English article.

It is with the help of these people that I can successfully complete the experiment, complete the paper, and thank them for their help.

\section{References}

[1] J. Jiang, C. Liu, Control aniline pollutants from printing and dyeing industries, China Environ News. 17 (2015):55-56.

[2] Li Xiaoge. Ecological management of Textile dyeing sludge [D], Donghua University, 2009.

[3] Chen Hong. Effects of Combined Fenton on Textile Dyeing Sludge Physicochemical Properties and Dewaterability [D]. Guangdong University of Technology, 2014.

[4] Xie Dawei. Treatment of Dyeing Wastewater from Dacron Yarn [J]. Environmental Protection, 1999 (04):28-30.

[5] Guo Qingwei, Yang Renbin, Wu Genyi, ect. Practice on the reformed treatment process for dyeing wastewater of nylon textile [J]. Industrial Water Treatment, 2004 (05):70-73.

[6] Dos Santos A B, Cervantes F J, Van Lier J B. Review of paper on current technologies for decolourisation of textile wastewaters; Perspectives for anaerobic biotechnology [J]. Bioresourches Technology, 2007, 98 (12):2369-2385.

[7] Ning Xunan, Wei Peitao, Liu jingyong, ect. Co-Combustion Characteristics and Kinetics of Textile Dyeing Sludge and Sawdust [J]. Journal of Combustion Science and Technology, 2012, 18 (02):131-138.

[8] Zhang Hedong, Gao Zuopeng, Ao Wenya, ect. Characterzation and analysis of textile sludge char from moving bed pyrolyser under microwave irradiation [J]. CIESC Journal, 2017, 68 (06):
2510-2518.

[9] Feng Yinfang, Ning Xunan, Wu Junji, ect. Effects of potassium ferrate conjunction with ultrasound on textile dyeing sludge dewaterability.t $[\mathrm{J}]$. Chinese Journal of Environmental Engineering, 2016, 10 (07):3787-3792.

[10] Chen Hong, Ning Xunan, Luo Haijian, ect. Influence of bioleaching-Fenton oxidation on textile dyeing sludge dewatering performances $[\mathrm{J}]$. Chinese Journal of Environmental Engineering, 2014, 8 (04):1641-1646.

[11] Wawrzynczyk J Recktenwald M, Norrlow O, et al. The function of cation binding agents in the enzymatic treament of municipal sludge [J]. Water Res, 2008, 42 (6-7): 1555-1562.

[12] Beijer R, Enzymatic treatment of wastewater sludge in presence of a cation binding agent improved solubilisation and increased methane production [D]. Sweden Linkopings University, 2008.

[13] Ahuja S K, Ferreira G M, Moreira A R. Utilization of enzymens for environmental applications [J]. Crit Rev Biotechnol, 2004, $24(2-3): 125-154$.

[14] He Dian, Wang Feng. A review of the detection methods of activated sludge activity [J]. Science and Technology Information, 2010 (01):381-382.

[15] Sun Xiaoying, Zhang Tiefan, Nie Yinjin, ect. Determination of Specific Oxygen Consumption Rate of Activated Sludge and Its Application in Wastewater Treatment Plants [J]. Tianjin Construction Science and Technology, 2009, 19 (06): 56-59.

[16] Xu Xiaolu, Shen Xiuying. Evaluation of active indicator of activated sludge [J]. Chinese Journal of Environmental Science, 1993 (02):58-62+95.

[17] Luo Huining. Determination of Chemical Oxygen Demand (COD) by Microwave Digestion [J]. Guangxi \& Development of Chemical Industry, 2003 (03):25-26.

[18] Huang Qing. Comparison of Microwave Digestion Method and Standard Return Method for Determination of COD [J]. Science and Technology Innovation Herald, 2013 (17):58.

[19] Zhong Fangxiao, Ren Haihua, Li Yan. Comparison of methods in Determination of polysaccaride content [J]. Lishizhen Medicine and Materia Medica Research, 2007 (08):1916-1917.

[20] Lu Ping, Yu Tongquan, Wang Shuying, ect. A review on determination of protein [J]. Journal of Beijing Agricultural College, 2006 (02):65-69.

[21] Yu Jing. Enhanced enzymatic hyydrolysis of excess sludge by surfactant [D]. Hu Nan University, 2011.

[22] Kong Wangshen, Liu Yan. Adsorption of a dye by sludge and the roles of extracellular polymeric substances [J]. Environmental Science, 2007 (12):2716-2721.

[23] Cao Jiashun, Zhu Zheying, Fang Fang, ect. Characteristics of extracellular polymeric substances (EPS) in the azo dye wastewater treated by activated sludge [J]. Acta Scientiae Circumstantiae, 2013, 33 (09):2498-2503.

[24] Xu Hongliang, Wu Xiaoying, Zhen Pin. Effect of extracellular polymer substances on wastewater treatment [J]. Environmental Science and Technology, 2005 (S1):121-122+124. 
[25] Shanableh A, Jomaa S. Production and transformation of volatile fatty acids from sludge subjected to hydrothermal treatment. Water Sci. Technol. 2001, 44:129-135. 